\title{
Congress cool on research funding proposals
}

Washington. A plan to centralize and streamline the allocation of US research and development (R\&D) funding received a frosty reception in Congress last week, when members of both political parties on the Science Committee in the House of Representatives attacked its most important proposals.

The plan was put forward last November by a panel of the National Academy of Sciences chaired by Frank Press, former science adviser to US president Jimmy Carter (see Nature 378, 426; 1995). It would exclude \$30 billion of military development work from the science and technology budget, and require Congress to consider the remaining budget as a single entity.

Both George Brown (Democrat, California), the senior Democrat on the Science committee, and Vernon Ehlers (Republican, Maryland), a former physicist who wields growing influence on the Republican side, attacked the plan in a hearing on 28 February. They argued that the R\&D budget would be harder to defend if it was shorn of the military development component, and that an additional step in the congressional budget process was unnecessary.

But Robert Walker (Republican, Pennsylvania), chairman of the Science Committee until his retirement this November, welcomed the Press report. He said he would continue to push for the central consideration of the research budget by the Congress.

Walker nevertheless asked Press why the $\$ 30$ billion should be excluded from the \$75billion annual R\&D budget "when it uses so much of the nation's scientific resource and talent". Press replied that the military development work "is not R\&D as most countries of the world define it".

But Ehlers said that while this proposal might be good logic, it was bad politics. "It's very logical and rational, but I have to worry about its political ramifications," he told Press, adding that a single research budget could be "a very tempting target" for budget-cutters.

Ehlers also pointed to some seldomnoted advantages of the existing appropriations process. There is, for example, "a lot of specific expertise in Congress about specific areas of the [research] budget". Ehlers acknowledged that he had been influenced by criticisms of Press's proposals made by D. Allan Bromley, dean of engineering at Yale University, who had been President George Bush's science adviser.

Meanwhile, Democrats on the committee focused on the implicit assumption of the

\section{US politicians play the numbers game}

Washington. Last July, the American Association for the Advancement of Science (AAAS) announced to a startled world that it expected Congress to cut non-defence research and development (R\&D) by one-third by 2002 . Since then, the number has assumed a life of its own. Most recently, it was used by Al Gore, the vice president, to attack Republican science policy (see Nature 379, 570; 1996).

So when Frank Press - wrongly, as it turned out - told the House of Representatives Science Committee last week that the AAAS was about to "back off from that projection", Republicans could scarcely conceal their glee. Robert Walker, chair of the committee, told the hearing he was "delighted", adding that he had been "disappointed that [the AAAS] used it in the way that they did".

After the hearing, Walker denied that his statements were an attack on the AAAS, which he said had "picked the figure up" from George Brown (Democrat, California), who made a similar analysis last spring. In fact, the AAAS got its figures from the seven-year 'concurrent budget resolution' passed by both houses of Congress last June. It found that the total non-defence R\&D would fall from $\$ 34.2$ billion in 1995 to $\$ 28.5$ billion in 2002. Making reasonable assumptions about inflation, this would be worth $\$ 22.9$ billion in 1995 dollars, a reduction of 32.9 per cent.

"We stood by the analysis then and we stand by it now," says Al Teich of AAAS. "But since then [last June] the Congress has been a lot kinder to nondefence R\&D than it said it would be." For 1996, for example, appropriations committees have not made anything like the \$4-billion cut in R\&D spending that the seven-year plan demanded.

The appropriations process for 1996 - due to be completed by 1 October 1995 but not yet finished - proved just how tough it was for even a freshly-elected, anti-spending Congress to cut actual programmes. This year, with elections pending, many observers say cuts will be even tougher to make, and spending could diverge still further from the harsh targets in last year's budget resolution.

This pattern could be repeated in future - or reversed. After all, both Congress and the Clinton administration are pledged to balance the budget by 2002 . Perhaps the White House will now publish its own figures, explaining how this will be achieved.
Press report that research budgets will decline. Brown said that the report failed to say whether its objectives could be met under current budget plans. "There comes a point when the whole research enterprise is at risk, and the problem cannot be solved

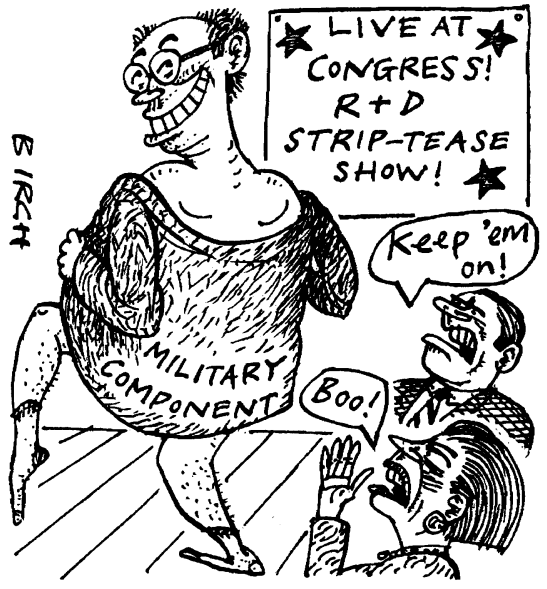

by better resource allocation," he said. Brown also expressed unhappiness at Press's handling of research allocation issues.

Asked directly if the objectives could be met if civilian R\&D spending was cut by 33 per cent by 2002 , as has been projected by the American Association for the Advancement of Science (AAAS), Press said "no", before adding: "I think the AAAS may be backing off from that projection, in the light of recent events." The AAAS denies that it is doing any such thing (see box, below left).

Connie Morella (Republican, Maryland), chair of the technology subcommittee, joined Democrats in expressing concern about Press's criticism of technology transfer programmes. The report criticized, in particular, the Advanced Technology Program, administered by the National Institute of Standards and Technology in Morella's district. Press said he had meant only that the programme should be thoroughly evaluated in comparison with other programmes.

Walker, the committee chairman, has warmly welcomed the Press report for two reasons. First, it echoes his own view that Congress should do more to consider the science budget across all agencies. Second, Press, rather than ignoring his congressional brief and simply asking for more money, chose to confront a new fiscal environment in which difficult choices must be made.

But Democrats think that Press went too far in tailoring his report - which was originally requested by senators of both parties - to the tastes of the new Republican majority. There is a chance, albeit a slim one, that the Democrats will regain control of the House next November. If they do, says Brown, the Press report will end up "in some obscure file somewhere".

Colin Macilwain 